\title{
Mechanisms of Regulation of Glycogen Phosphorylase Activity in Saccharomyces carlsbergensis
}

\author{
By JÖRN-ULLRICH BECKER \\ Botanisches Institut der Universität Bonn, Kirschallee 1, D-5300 Bonn 1, \\ Federal Republic of Germany
}

(Received 17 March 1981; revised 9 June 1981)

The content of glycogen phosphorylase (1,4- $\alpha$-D-glucan:orthophosphate $\alpha$-D-glucosyltransferase, EC 2.4.1.1) in yeast (Saccharomyces carlsbergensis) cells depended on the growth phase. Cells of the early exponential phase under carbohydrate-limited conditions showed low, but significant, phosphorylase activity; the activity markedly increased in the late exponential growth phase, concomitant with the appearance of measurable phosphorylase antigen. This pointed to an induction of the enzyme. During the interexponential phase (the slow proliferation phase during the diauxic growth of the culture, when the cells switch to utilization of accumulated ethanol) and the stationary growth phase, phosphorylase concentration remained constant while its specific molecular activity increased further, probably caused by conversion of the enzyme to an active form. During transition of stationary phase cells to growth, phosphorylase activity and concentration slowly decreased in the cells at a rate compatible with dilution by newly synthesized proteins. A residual activity always remained, which could be attributed to the presence of active phosphorylase, detectable by activity staining after gel electrophoresis in the presence of glycogen. No direct correlation could be detected between the specific molecular activity of phosphorylase and glycogen metabolism. This indicated that covalent modification of the enzyme regulated the total capacity of the enzyme available to the cell, rather than the actual activity limiting glycogen breakdown.

\section{INTRODUCTION}

Since the discovery of the regulation of muscle glycogen phosphorylase activity by reversible phosphorylation, this process has been linked to a host of different regulatory mechanisms as diverse as gene activation, membrane transport and enzyme regulation (Cohen, 1980). Yeast is the only micro-organism discovered so far in which glycogen phosphorylase could be activated by phosphorylation in vitro (Fosset et al., 1971). In muscle, a clear-cut relationship between glycogenolysis and phosphorylase activity has been established (Helmreich \& Cori, 1965). Whether this mechanism is involved in the activation of glycogenolysis in the intact yeast cell is not known. Only the correlation of glycogen synthesis and activity of glycogen synthase (EC 2.4.1.11) has been investigated (Rothman-Denes \& Cabib, 1970; Becker, 1977). Because yeast cells of different growth phases differ markedly in their ability to synthesize and degrade glycogen, other mechanisms for the regulation of phosphorylase activity, typical for micro-organisms - e.g. induction and repression or catabolite inactivation (Holzer, 1976) - must be considered.

In this study, the activity and concentration of phosphorylase (1,4- $\alpha$-Dglucan:orthophosphate $a$-D-glucosyltransferase, EC 2.4.1.1) were determined at various growth phases and under conditions known to have a drastic influence on glycogen metabolism (Becker et al., 1979), in order to determine whether or not direct correlations 
exist between phosphorylase activity and glycogen metabolism and whether the enzyme is subject to other regulatory mechanisms.

\section{METHODS}

Chemicals. Biochemicals were products of Boehringer. The agarose for immunoelectrophoresis (Type 1, low EEO) was purchased from Sigma. All other chemicals used were of analytical grade.

Growth. The experiments were carried out with Saccharomyces carlsbergensis (ATCC 9080) cells, grown under carbohydrate- (C-) or nitrogen- (N-) limited conditions (Becker et al., 1979). Cell proliferation was followed by determination of the $A_{546}$ and the wet weight of the cell pellet after centrifugation at $3000 \mathrm{~g}$ for $5 \mathrm{~min}$. The cell concentration of suspensions was based on this wet weight.

Preparation of cells for transition from stationary phase to growth. Cells were grown for $24 \mathrm{~h}$ under $\mathrm{C}$ limitation and harvested by centrifugation. To four batches of $1225 \mathrm{ml}$ culture medium $\left(28^{\circ} \mathrm{C}\right) 4 \mathrm{~g}, 2 \mathrm{~g}, 1 \mathrm{~g}$ or $0.5 \mathrm{~g}$ of yeast cells were added, and growth was followed by measuring the $A_{546}$. In order to avoid induction of phosphorylase, cells were harvested at a cell concentration of 5-6 $\mathrm{mg}$ wet wt $\mathrm{ml}^{-1}$.

Treatment of cells to induce glycogen breakdown or synthesis. Cells from the stationary phase of a C-limited culture were suspended $\left(50 \mathrm{mg}\right.$ cells $\mathrm{ml}^{-1}$ ) in incomplete medium (lacking $\mathrm{N}$ sources), resulting in glycogen synthesis, or in complete growth medium, causing glycogen breakdown. After $20 \mathrm{~min}$, either the cells were harvested by centrifugation $(2 \mathrm{~min}, 3000 \mathrm{~g}$ ), or $5 \mathrm{ml}$ of the total cell suspension were frozen in a X-press (AB Biox Nacka, Sweden) at $-28^{\circ} \mathrm{C}$ to break the cells.

Preparation of cell extracts for enzyme assay. Cells were harvested at different growth phases. A cell slurry, prepared by addition of $10 \%(\mathrm{v} / \mathrm{v})$ of ice-cold water, was passed through an Aminco French pressure cell at $8 \mathrm{t}$ pressure into an equal volume of $100 \mathrm{~mm}$-sodium succinate buffer, pH 5.8 , with $1 \mathrm{~mm}$-EDTA, $0.2 \mathrm{~mm}$ phenylmethane sulphonyl fluoride and $0.01 \%(\mathrm{w} / \mathrm{v})$ benzamidine. $\mathrm{HCl}$ added as protease inhibitors. The mixture was centrifuged for $20 \mathrm{~min}$ at $48000 \mathrm{~g}$ in a refrigerated centrifuge and the supernatant filtered through glass wool. A portion was desalted by passage through a PD-10 column (Pharmacia) equilibrated with $100 \mathrm{~mm}$-sodium succinate buffer containing the additions mentioned above.

Alternatively, the cells were broken in the frozen state with an X-press, without prior removal from the incubation medium, and kept at $-28^{\circ} \mathrm{C}$ until phosphorylase activity could be determined. The homogenates were thawed in $0.5 \mathrm{ml} 500 \mathrm{mM}$-sodium succinate buffer, $\mathrm{pH} 5 \cdot 8$, with $200 \mathrm{mM}-\mathrm{NaF}$ and $20 \mathrm{mM}$-EDTA. Cell debris was removed by centrifugation $(48000 \mathrm{~g}$ for $10 \mathrm{~min}$ ) and phosphorylase activity immediately determined. Comparable specific phosphorylase activities in identical yeast batches were observed with the two methods, although the extracts obtained with the X-press were generally somewhat more active. In both types of extract, phosphorylase activity changed only slowly $\left(10-20 \%\right.$ per day) at $0{ }^{\circ} \mathrm{C}$.

Protein was determined by the biuret method (Gornall et al., 1949) using bovine serum albumin as a standard and corrected for turbidity by addition of $1 \%(\mathrm{w} / \mathrm{v}) \mathrm{KCN}$. In the X-press, protein was determined after precipitation with $10 \%(\mathrm{w} / \mathrm{v})$ trichloroacetic acid.

Glycogen phosphorylase assays. In the gel filtrates, enzyme activity was assayed in the direction of amylose synthesis (S-test) and of glycogen breakdown (phosphorolytic direction, P-test; Becker, 1979). In order to detect interference of acid phosphatase, the ratio of the activities of the S-test and the P-test (S/P) was calculated. Values above 4.5 indicate interference by acid phosphatase. Specific activity is given in units (U) (mg phosphorylase $)^{-1}$ as determined immunologically. One unit corresponds to the production of $1 \mu \mathrm{mol} \mathbf{P}_{\mathrm{i}}$ or $1 \mu \mathrm{mol}$ glucose-1-phosphate $\mathrm{min}^{-1}$, in the S-test or the P-test, respectively.

Immunological determinations. Monospecific antibodies against pure yeast phosphorylase were prepared as described earlier (Becker, 1979). Phosphorylase antigen was quantified by 'rocket immunoelectrophoresis' according to Laurell (1966). Dilutions (5 $\mu \mathrm{l}$ ) of crude extracts containing 2-20 $\mathrm{mg}$ protein $\mathrm{ml}^{-1}$ were placed in wells of $2.5 \mathrm{~mm}$ diameter in a $1 \%$ agarose layer with anti-phosphorylase serum $(0.1-0.2 \mathrm{ml})$. Electrophoresis was run for $5 \mathrm{~h}$ at $300 \mathrm{~V}$ in a flat-bed electrophoresis chamber (Behringwerke, Frankfurt am Main, F.R.G.). The gel was washed twice with $0.9 \%(\mathrm{w} / \mathrm{v}) \mathrm{NaCl}$ and distilled water and stained, after drying, with Coomassie blue R-250. The height of the precipitin rockets was measured and the amount of antigen determined from a calibration curve showing the height of the precipitin rockets obtained with known amounts of pure baker's yeast phosphorylase $(0.05-1.00 \mu \mathrm{g})$ run on the same plate. The detection limit of the method was approximately $0.01 \mu \mathrm{g}$ phosphorylase. The antibody reacted equally well with active and inactive forms of phosphorylase, with equal amounts of pure phosphorylase of different specific activity giving rise to identical rockets within the limits of the accuracy of the assay.

Gel electrophoresis. Electrophoresis was carried out according to Davis et al. (1967), in the presence of glycogen. Phosphorylase activity was detected by immersing the gel for $2-12 \mathrm{~h}$ in the substrate used for the S-test; the amylose produced was stained with $0.1 \% \mathrm{KI}_{3}$. For crossed immunoelectrophoresis, the gel was embedded in the agarose used for immunoelectrophoresis and subjected to an electric field at right angles to the gel, under the conditions used for the 'Laurell rocket' method. Protein was stained with Coomassie blue R-250. 
Partial purification of phosphorylase. Cells of $S$. carlsbergensis grown under C limitation were harvested in the early exponential growth phase $\left[9 \mathrm{mg}\right.$ cells $\left.(\mathrm{ml} \mathrm{medium})^{-1}\right]$ with $75 \mathrm{~mm}$-glucose remaining in the culture medium, and in the stationary phase ( $22 \mathrm{mg}$ cells $\left.\mathrm{ml}^{-1}\right)$. The specific activities (S test) of phosphorylase in the crude extracts from the two growth phases were $13 \mathrm{mU}$ (mg protein $)^{-1}$, and $110 \mathrm{mU}$ (mg protein $)^{-1}$, respectively. Cells from either exponential or stationary growth phases were homogenized and the phosphorylase was purified as far as the precipitation step at $60 \%$ saturation of ammonium sulphate as described previously (Becker, 1979). The sediment was dissolved in $5 \mathrm{ml} 10 \mathrm{mM}$-imidazole buffer, $\mathrm{pH} 6.2$ (with EDTA and the protease inhibitors given above), and desalted through two PD-10 columns. The eluate $(7 \mathrm{ml})$ was applied to a small column containing $10 \mathrm{ml}$ DEAE-Sephacel (Pharmacia), equilibrated with the imidazole buffer. The column was washed with imidazole buffer, then with buffer plus $100 \mathrm{mM}-\mathrm{NaCl}$, and phosphorylase activity was eluted with buffer plus $400 \mathrm{mM}-\mathrm{NaCl}$. Protein was precipitated at $60 \%$ saturation of ammonium sulphate, dissolved in a small amount of the $100 \mathrm{~mm}$-sodium succinate buffer described above and dialysed against the same buffer (two changes). The retained material was used for the experiments. Recovery of activity was $23 \%$ and $13 \%$ (at a $3 \cdot 8$ - and $4 \cdot 2$-fold purification) from the extracts of exponential and stationary cells, respectively. This result is typical for purifications to this step.

\section{RE S U L T S}

\section{Phosphorylase concentration and activity of yeast cells at different phases of C-limited growth}

Yeast cells (Saccharomyces cerevisiae) (Rothman-Denes \& Cabib, 1970) and $S$. carlsbergensis (Becker et al., 1979) in the early exponential growth phase neither contain appreciable amounts of glycogen, nor are they capable of glycogen synthesis. The polysaccharide appears only at the late exponential growth phase and declines very slowly after transition to interexponential and stationary phases. [The interexponential phase is the slow proliferation phase during the diauxic growth of the culture, when the cells switch to utilization of accumulated ethanol (Becker et al., 1979).] Phosphorylase activity also drastically changes during transition from early exponential to interexponential growth phases (Table 1). The change was more impressive when the concentration of phosphorylase was determined and the specific molecular activity [U (mg enzyme $\left.)^{-1}\right]$ calculated. As shown in Table 1 (Column 5), specific molecular activity was lower during the interexponential growth phase than in the stationary phase. The values obtained corresponded to mixtures of active and inactive forms of phosphorylase. The extract of cells from the early exponential phase contained less than $0.01 \mu \mathrm{g}$ phosphorylase ( $\mathrm{mg}$ total protein $)^{-1}$, which is the detection limit of the assay. Nevertheless, low but significant activity could be detected which, in several experiments, accounted for about $10 \%$ of the activity found in stationary phase cell extracts.

In order to test whether an isoenzyme was responsible for the low phosphorylase activity in exponentially growing cells, the enzyme was isolated and concentrated for electrophoretic characterization from exponential and stationary phase cells (Fig. 1a, b). Glycogen phosphorylase was detected by crossed immunoelectrophoresis and activity staining. For the latter method, it was necessary to incorporate $5 \mathrm{mg}$ glycogen $\mathrm{ml}^{-1}$ in the gel matrix in order to prevent total inactivation of phosphorylase. Activity staining showed a weak activity band close to the origin of the gels in the preparation from the exponential phase cells (Fig. 1a) and a strong activity band in this position in gels of the stationary phase cells (Fig. $1 b$ ).

In the crossed immunoelectrophoresis, no antigen band could be detected in the protein isolated from exponential phase cells (Fig. 1 $a$ ), which was in contrast to a strong reaction observed with the same amount of protein from stationary phase cells (Fig. $1 b$ ). Surprisingly, the activity and antigen bands did not coincide. In order to clarify this puzzling observation, pure yeast phosphorylase was subjected to electrophoresis under the same conditions in the presence of $5 \mathrm{mg}$ glycogen $\mathrm{ml}^{-1}$ in the gel matrix (Fig. 1c-1) or $0.01 \mathrm{mg}$ glycogen $\mathrm{ml}^{-1}$ (Fig. $1 c-2)$. Under the former condition, the activity band remained close to the gel origin as in the crude preparations. The bulk of protein migrated to a position where phosphorylase antigen was detected in the preparation from stationary cells (Fig. $1 b$ ). Upon longer incubation, phosphorylase activity could also be observed at this location (not shown). At low glycogen 
Table 1. Activity of glycogen phosphorylase in crude extracts of $S$. carlsbergensis cells

Activity was determined in extracts of cells in the early exponential (1), interexponential (2) and stationary (3) phases of C-limited growth, and of cells in the stationary phase of N-limited growth (4).

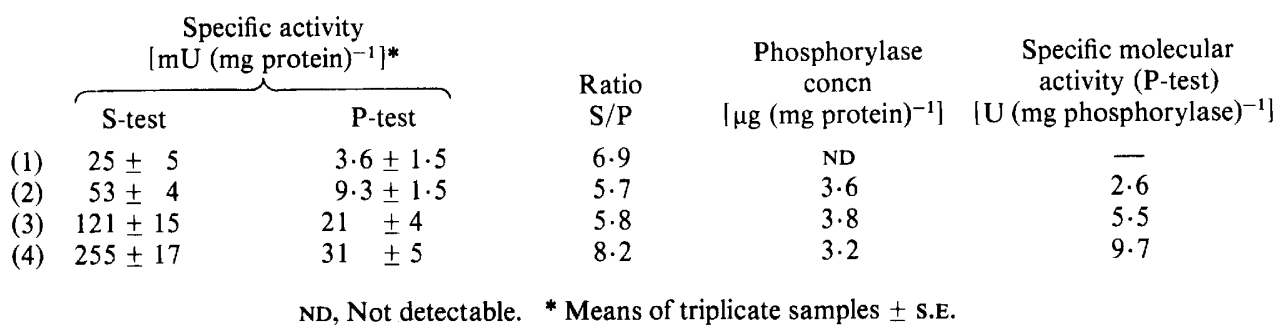

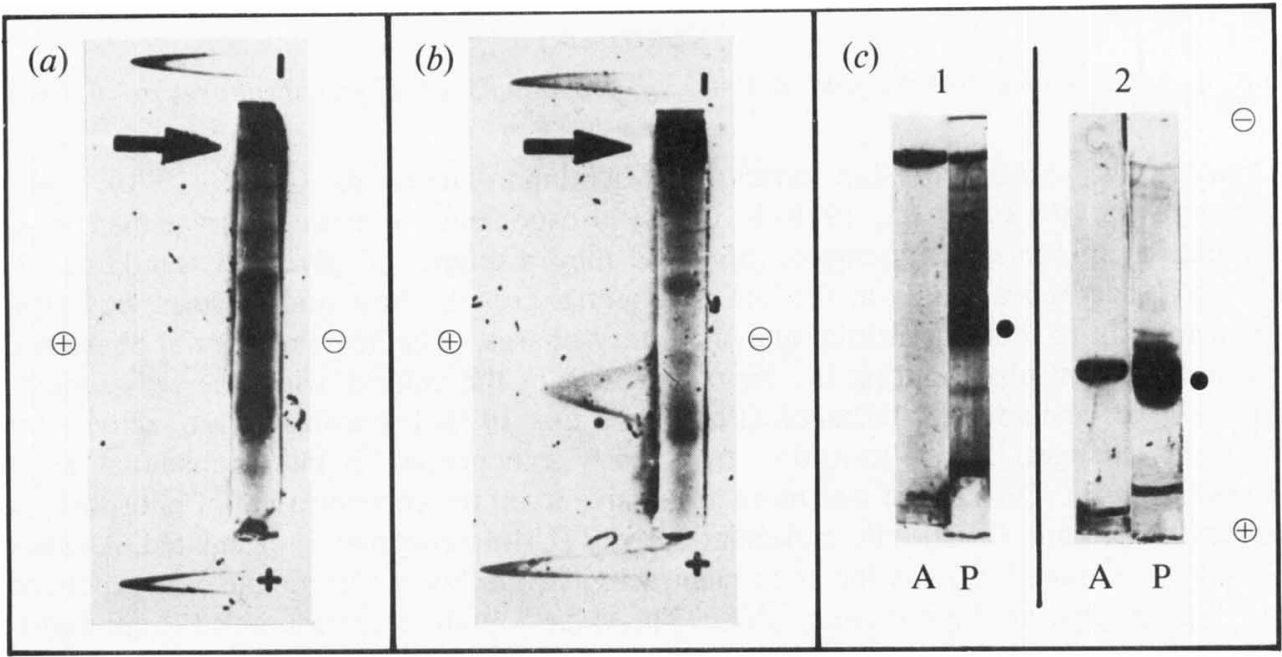

Fig. 1. Electrophoretic characterization of partially purified phosphorylase ( $100 \mu \mathrm{g}$ protein per gel) in extracts from cells of the early exponential $(a)$ and stationary $(b)$ phases of growth under carbohydrate limitation, compared with the pattern obtained by electrophoresis of pure phosphorylase $(15 \mu \mathrm{g})$ in the presence of glycogen at $5 \mathrm{mg} \mathrm{ml}^{-1}(c-1)$ or $0.01 \mathrm{mg} \mathrm{ml}^{-1}(c-2)$. The gels in $(a)$ and $(b)$ were first stained for enzyme activity (arrows), then for protein. The gel for crossed immunoelectrophoresis contained $0.25 \mathrm{ml}(a)$ or $0.15 \mathrm{ml}(b)$ antiserum. For calibration, $0.5 \mu \mathrm{g}$ pure phosphorylase was applied to both sides of the gel. The dots in $(c-1)$ and $(c-2)$ denote the location of the main protein band. A, activity stain; P, protein stain.

concentration, the activity and the protein band coincided (Fig. 1c-2). The main protein band also migrated further and did not show the tailing observed in the presence of the high glycogen concentration. These observations indicate that most of the phosphorylase was inactivated during gel electrophoresis, thus lowering the affinity for glycogen and resulting in an increase of mobility, while the remaining active form was strongly retarded by binding to glycogen.

\section{Mechanism of lowering of phosphorylase concentration in growing cells}

Since cells in the early exponential growth phase contain only very little phosphorylase, it seemed interesting to know how phosphorylase concentration is lowered in growing cells. There are two possibilities. The first is that synthesis of phosphorylase is simply repressed in growing cells, which results in a progressive dilution of the enzyme by newly synthesized proteins. The total amount of the phosphorylase should, therefore, remain constant in the 
Table 2. Phosphorylase activity and concentration in S. carlsbergensis cells during transition from stationary phase to growth

Batches of medium inoculated with $4 \mathrm{~g}$ (culture 1), $2 \mathrm{~g}(2), 1 \mathrm{~g}$ (3) or $0.5 \mathrm{~g}$ (4) of cells were harvested when they had grown to a cell concentration of $5-6 \mathrm{mg}$ wet wt $\mathrm{ml}^{-1}$ (see Methods). Phosphorylase activity and concentration were determined in gel filtrates of crude extracts from the initial inoculum and from each culture at harvest.

\begin{tabular}{|c|c|c|c|c|c|c|c|}
\hline \multirow[b]{2}{*}{ Sample } & \multirow{2}{*}{$\begin{array}{l}\text { Incu- } \\
\text { bation } \\
\text { time } \\
\text { (min) }\end{array}$} & \multicolumn{2}{|c|}{$\begin{array}{c}\text { Specific activity } \\
{\left[\mathrm{mU}(\mathrm{mg} \text { protein })^{-1}\right]}\end{array}$} & \multirow{2}{*}{$\begin{array}{c}\text { Ratio } \\
\text { S/P }\end{array}$} & \multirow{2}{*}{$\begin{array}{l}\text { Phosphorylase } \\
\text { concn }[\mu \mathrm{g} \\
\left.(\mathrm{mg} \text { protein })^{-1}\right]\end{array}$} & \multirow{2}{*}{$\begin{array}{c}\text { Dilution } \\
\text { by cell } \\
\text { proliferation* } \\
(- \text { fold })\end{array}$} & \multirow{2}{*}{ 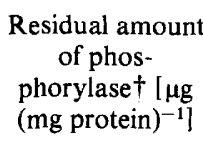 } \\
\hline & & S-test & P-test & & & & \\
\hline Inoculum & - & 150 & 30 & $5 \cdot 0$ & 2.4 & - & 2.4 \\
\hline Culture 1 & 180 & 30 & $4 \cdot 0$ & $7 \cdot 5$ & 1.25 & 1.9 & $2 \cdot 4$ \\
\hline Culture 2 & 255 & 23 & 4.4 & $5 \cdot 2$ & 0.50 & 3.9 & 1.95 \\
\hline Culture 3 & 330 & 37 & $4 \cdot 1$ & $9 \cdot 0$ & 0.16 & $5 \cdot 6$ & 0.9 \\
\hline Culture 4 & 420 & 30 & $3 \cdot 8$ & 7.9 & $<0.05$ & $11 \cdot 5$ & - \\
\hline
\end{tabular}

* Cell proliferation was calculated by comparing the cell mass (wet wt) of the cells harvested with that of the inoculum.

† The residual amount of phosphorylase was calculated by multiplying the phosphorylase concentration (column 6) by the dilution by new protein (column 7). The total amount of phosphorylase in the culture could not be calculated because the percentage of cells broken in the French press differed between the samples.

culture batch or decrease at a rate identical to protein turnover. The second possibility is that phosphorylase is subject to catabolite inactivation (Holzer, 1976). In this case, the enzyme is actively destroyed by a protease. Consequently, the total amount of phosphorylase in the culture should decline rapidly after transition to inactivating conditions. In order to distinguish between these alternatives, phosphorylase concentration was measured for several generations after resuspension in fresh growth medium of cells grown under $\mathrm{C}$ limitation (Table 2). The total amount of phosphorylase did not stay constant for several generations, but it declined only slowly. After one generation, the original amount was still present; only after four generations was phosphorylase antigen not detectable. In contrast, enzyme activity declined much faster, which pointed to a rapid inactivation of phosphorylase during the first $3 \mathrm{~h}$.

\section{Phosphorylase in stationary phase cells grown under $N$ limitation}

As under $\mathrm{C}$-limited growth, cells cultured under $\mathrm{N}$ limitation start to synthesize glycogen only during the late exponential growth phase. Stationary phase cells grown under these conditions contain only $25 \%$ of the protein present in cells from C-limited cultures. Phosphorylase concentration, determined immunologically, was lowered by about the same factor. Its specific molecular activity, on the other hand, was higher, which resulted in about the same total activity per cell as in yeast grown under C limitation (Table 1).

\section{Phosphorylase activity in cells from a stationary phase culture synthesizing or degrading glycogen}

In order to test whether or not the specific molecular activity of phosphorylase was different in cells accumulating or degrading glycogen, cells were suspended either in a solution of mineral salts (incomplete medium) or in the complete medium (Table 3). Under the former conditions, the cells synthesized glycogen at a rate of $0.57 \mu \mathrm{mol} \mathrm{min}^{-1}(\mathrm{~g} \text { cells })^{-1}$, while under the latter it was degraded $\left(0.63 \mu \mathrm{mol} \mathrm{min}^{-1} \mathrm{~g}^{-1}\right)$. After $20 \mathrm{~min}$ incubation, the cells were broken in the French press (processing time was less than $2 \mathrm{~min}$ ). The effluent from the press was injected directly into $\mathrm{H}_{2} \mathrm{O}$ with protease inhibitors or into sodium succinate buffer with the same inhibitors plus $\mathrm{NaF}$ and EDTA in order to test whether these additions influence total phosphorylase activity by inhibition of phosphorylase phosphatase. Phosphorylase 
Table 3. Phosphorylase activity and concentration in extracts from $S$. carlsbergensis cells synthesizing or degrading glycogen

\begin{abstract}
Induction of glycogen breakdown (complete medium) or synthesis (incomplete medium) was as described in Methods. The effluents from the French press were diluted into $\mathrm{H}_{2} \mathrm{O}$ containing protease inhibitors or into $100 \mathrm{~mm}$-sodium succinate buffer containing the same inhibitors plus $5 \mathrm{mM}$-EDTA and $20 \mathrm{~mm}-\mathrm{NaF}$. The PD-10 columns used for gel filtration were equilibrated with the corresponding solutions.
\end{abstract}

\begin{tabular}{|c|c|c|c|c|c|}
\hline & \multicolumn{2}{|c|}{$\begin{array}{c}\text { Specific activity } \\
{\left[\mathrm{mU}(\mathrm{mg} \text { protein })^{-1}\right]^{*}}\end{array}$} & \multirow{2}{*}{$\begin{array}{l}\text { Ratio } \\
\text { S/P }\end{array}$} & \multirow{2}{*}{$\begin{array}{c}\text { Phosphorylase } \\
\text { concn } \\
{\left[\mu \mathrm{g}(\mathrm{mg} \text { protein })^{-1}\right]}\end{array}$} & \multirow{2}{*}{$\begin{array}{c}\text { Specific molecular } \\
\text { activity (P-test) } \\
{\left[\mathrm{U}(\mathrm{mg} \text { phosphorylase })^{-1}\right]}\end{array}$} \\
\hline & S-test & $P$-test & & & \\
\hline \multicolumn{6}{|c|}{ Complete medium } \\
\hline $\mathrm{H}_{2} \mathrm{O}$ & $154 \pm 20$ & $22 \pm 4$ & $7 \cdot 1$ & - & -- \\
\hline Succinate & $210 \pm 30$ & $31 \pm 6$ & $6 \cdot 7$ & $4 \cdot 6$ & $6 \cdot 7$ \\
\hline \multicolumn{6}{|c|}{ Incomplete medium } \\
\hline $\mathrm{H}_{2} \mathrm{O}$ & $144 \pm 17$ & $25 \pm 5$ & $5 \cdot 7$ & - & - \\
\hline Succinate & $194 \pm 26$ & $31 \pm 6$ & $6 \cdot 2$ & $4 \cdot 2$ & $7 \cdot 4$ \\
\hline
\end{tabular}

activity and concentration were determined in gel filtrates. Phosphorylase activity in extracts from cells synthesizing or degrading glycogen was identical. Owing to inhibition of phosphorylase phosphatase by succinate and fluoride, the samples in this buffer were slightly more active in both cases. Phosphorylase concentration was, as expected, identical in both extracts.

Because phosphorylase could have been converted to an inactive form during harvesting and preparation of the cells for extraction, a similar experiment was performed in which the cells were rapidly frozen in the incubation medium and homogenized with an X-press, thus effectively inhibiting any interconversion of the enzyme. The cells were incubated as above [rates of glycogen synthesis and breakdown 2.0 and $0.8 \mu \mathrm{mol}$ glucosyl units $\min ^{-1}$ (g cells) ${ }^{-1}$, respectively], as a $5 \%(\mathrm{w} / \mathrm{v})$ suspension, but the total suspension was frozen and the cells were broken in an X-press. Activity, determined in the S-test, amounted to ( \pm S.E.) $320 \pm$ $25 \mathrm{mU}$ in the extract from the cells degrading glycogen and $340 \pm 15 \mathrm{mU}$ in the one from cells synthesizing it. These values are not significantly different from each other. Apparently, the specific molecular activity of phosphorylase depended on the growth phase of the cells, which did not change whether the cells synthesized or degraded glycogen.

\title{
DISCUSSION
}

Phosphorylase in yeast is not a constitutive but an inducible enzyme which is synthesized during the late exponential growth phase. It is not known what signal triggers the synthesis. Glucose repression as known in bacteria can be ruled out since most of the glucose (about $60 \%$ ) was left in the growth medium at the time of induction. After transfer of the cells into fresh medium, phosphorylase synthesis was repressed, leading to a progressively lower phosphorylase concentration in the cells, which could be mostly attributed to dilution by newly synthesized proteins. The total amount of phosphorylase in the culture also declined slowly, although it should have stayed constant if synthesis alone was repressed. On the other hand, all cell proteins are subject to turnover (Schimke, 1975). Therefore, it is not surprising that a particular protein, no longer being produced, was eventually lost from the population or reduced to very low levels, as observed here.

This residual activity might have been due to an isoenzyme of phosphorylase not undergoing repression. The evidence obtained so far contradicted this assumption. On gel 
electrophoresis in the presence of glycogen, phosphorylase activity migrated to the same position as the enzyme from stationary phase cells, although the bulk of phosphorylase antigen exhibited a higher mobility. Experiments with pure phosphorylase suggested that the faster-moving protein was probably inactivated phosphorylase generated by the alkaline conditions during gel electrophoresis (Fosset et al., 1971). This hypothesis is supported by the following observations. (1) The different electrophoretic mobility of the active form of phosphorylase is only a consequence of the glycogen content of the gel and not due to different charges of two proteins, since in the presence of low glycogen concentration, the activity and main protein band coincide (Fig. 1c-2). (2) High glycogen concentration causes extensive tailing of the protein (Fig. $1 c-1$ ). This is probably a result of a time-dependent inactivation of phosphorylase. Active phosphorylase molecules, initially bound to glycogen, lose their affinity for it after inactivation and start to migrate, thus resulting in the smearing of the protein from the activity band to the main protein band. (3) Inclusion of $\mathrm{Mg}^{2+}$ (Fosset $e t$ al., 1971) partially prevented the inactivation of phosphorylase, leading to more phosphorylase protein being retained by glycogen (unpublished observations). This evidence does not completely rule out the presence of an isoenzyme which, in this case, must also be present in purified phosphorylase from commercial baker's yeast as in $S$. carlsbergensis cells.

Induction/repression is not the only mechanism by which phosphorylase activity in the cells is regulated. The molecular specific activity of phosphorylase changed characteristically during growth. In the late exponential and interexponential growth phases, the enzyme was extracted with low specific molecular activity; the activity rose during starvation or after transition to the stationary growth phase. Since no change of molecular specific activity of the enzyme was observed when cells from various growth phases were subjected to conditions favouring either glycogen breakdown or glycogen synthesis (for a representative experiment, see Table 3), interconversion of the enzyme between the active and inactive forms seems not to be involved in short-term regulation of glycogen metabolism, as observed in muscle (Helmreich \& Cori, 1965). The possibility that the enzyme was converted during harvesting and homogenization of the cells could not be completely ruled out, but seemed improbable since the extracts always displayed practically identical specific molecular activities depending only on the growth phase. If artificial conversions occurred during processing of the cells, one would expect very scattered data. Homogenization of the cells in the frozen state eliminated this possibility and still resulted in identical enzyme activity regardless of whether glycogen-synthesizing or glycogen-degrading cells were extracted.

The differences in specific molecular activity of phosphorylase during the growth of a cell culture suggest that interconversion of the enzyme by phosphorylation occurs as observed by Fosset et al. (1971) in vitro. The phosphorylases $a$ and $b$ described by these authors show differences in activity and sensitivity to effectors too small to be distinguished kinetically in crude extracts. Therefore, evidence for the occurrence of different forms of phosphorylase could only be derived from immunochemical analyses.

The strong dependence of the specific molecular activity of phosphorylase on the growth phase, but not on the actual occurrence of glycogen synthesis or breakdown, suggested a purpose for the conversion mechanism. In yeast, phosphorylase catalysing glycogen breakdown is induced, together with other enzymes involved in glycogen metabolism, at a time when the cells accumulate glycogen. At this time its specific molecular activity is low. Only during the stationary phase, when the cells depend on their endogenous reserves, is phosphorylase activated, thus enhancing the capacity of the cells for glycogen breakdown. Hence, the cells possess an additional mechanism to adjust the total capacity of the already induced enzyme in response to endogenous (or long-term environmental) conditions. The actual short-term regulation of the enzyme activity is then left to the concentrations of substrates and, perhaps, to hitherto unknown effectors of the enzyme. It could be shown that glycogen breakdown is stopped as soon as the cells accumulate glycogen, pointing to an effective regulation and elimination of a futile cycle. 
The author wishes to thank Miss B. Schwarz for her skilled technical assistance and Dr Tom Buckhout for critical reading of the text. The work was supported by the Deutsche Forschungsgemeinschaft.

\section{REFERENCES}

BECKER, J. U. (1977). Glycogen synthase in Saccharomyces carlsbergensis cells capable of oscillatory glycolysis. Archives of Microbiology 115, 181-184.

BECKER, J. U. (1979). Isolation and characterisation of an acid phosphatase interfering with phosphorylase determinations in crude extracts from yeast. Archives of Microbiology 123, 233-238.

Becker, J. U., VohmanN, H. J. \& EILERS-KöNIG, CHR. (1979). Glycogen metabolism in resting and growing cells of Saccharomyces carlsbergensis. Archives of Microbiology 123, 143-149.

CoHEN, P. (editor) (1980). Recently discovered systems of enzyme regulation by reversible phosphorylation. Amsterdam: Elsevier-North Holland.

Davis, C. H., Schliselfeld, L. D., Wolf, D. P., LeavitT, C. A. \& Krebs, E. G. (1967). Interrelationships among glycogen phosphorylase isozymes. Journal of Biological Chemistry 242, 48244833.

Fosset, M., Muir, L. W., Nielsen, L. D. \& Fischer, E. H. (1971). Purification and properties of yeast phosphorylase $a$ and $b$. Biochemistry 10, 41054113 .
Gornall, A. G., Bradawill, C. J. \& David, M. M. (1949). Determination of serum proteins by means of the biuret reaction. Journal of Biological Chemistry 177, 751-766.

Helmreich, E. \& Cori, C. F. (1965). Regulation of glycolysis in muscle. Advances in Enzyme Regulation 3, 91-107.

Holzer, H. (1976). Catabolite inactivation in yeast. Trends in Biochemical Sciences 1, 178-181.

LAURELl, C. B. (1966). Quantitative estimation of proteins by electrophoresis in agarose gels containing antibodies. Analytical Biochemistry 15, 45-53.

Rothman-Denes, L. B. \& Cabib, E. (1970). Two forms of yeast glycogen synthetase and their role in glycogen accumulation. Proceedings of the National Academy of Sciences of the United States of America 66, 967-974.

Schimke, R. T. (1975). On the properties and mechanism of protein turnover. In Intracellular Protein Turnover, pp. 173-186. Edited by R. T. Schimke \& N. Katunuma. New York: Academic Press. 